\title{
Value relevance of accounting data and financial crisis in Europe: an empirical analysis.
}

\author{
Alain Devalle \\ Assistant Professor - Department of Management \\ University of Turin, Faculty of Economics and Business \\ C.so Unione Sovietica 218 bis - 10134 Turin (ITALY) - Devalle@econ.unito.it
}

Received: September 12, 2012 Accepted: October 11, 2012 DOI: 10.5296/ijafr.v2i2.2527

\begin{abstract}
This paper aims at verifying the relationship between book value and market value for a four years period (2006-2009) in Europe, under IFRS. In particular, I used value relevance approach to measure whether net income or comprehensive income is more useful to understand the relationship between market data and financial data. Moreover, the paper analyzes the impact of financial crisis on the value relevance of accounting data. The examination period runs from a pre-crisis period (2006-2007) to an in-crisis period (2008-2009). Results shows that comprehensive income is more value relevant than net income. Furthermore, the financial crisis has a positive impact on value relevance.
\end{abstract}

Keywords: comprehensive income; value relevance; IFRS, net income, financial crisis. 


\section{Introduction}

In this research, I examine the consequences of economic turmoil in Europe on the association between accounting information and market values. Value relevance of net income and comprehensive income of European listed companies before and during the financial crisis (2006-2009) is analyzed.

Concerning the origin and effects of the financial crisis of 2007-2010 there is an enormous quantity of publications. The financial crisis started in USA in 2007 after the subprime loan "bubble" and subsequently affected the world economy. The main effect in Europe appeared from 2008 and the global economy is still weak. The financial crisis has an impact on social, economic and political life. In particular, with reference to economic contest, the crisis impact, between the others, on stock prices of listed companies (Mun et al, 2012). The aim of this paper is not to identify the causes of the financial crisis, but only to analyze the effect on the value relevance of accounting data.

In this context, this paper aims at verifying the relation between market data and book value in a financial crisis period. I address two primary questions in this study. First, what is the relationship between book value and market value for a four years period (2006-2009) in Europe, under IFRS? In particular, I used value relevance approach to measure whether net income or comprehensive income are more useful to understand the relationship between market data and financial data. Second, I analyzed the impact of financial crisis on the value relevance of accounting data. The examination period runs from a pre-crisis period (2006-2007) to an in-crisis period (2008-2009).

This paper aims at verifying the impact of financial crisis on value relevance by providing results which have been obtained by using accounting data reported under IFRSs. The aim of the paper is to verify the reaction of association between accounting data and market data in a period when financial crisis arises. Investors may find this study of particular interest to support their investment decisions. Thus, this paper aims at contributing to the large debate on performance with an analysis of the value relevance of comprehensive income under IFRSs.

The remainder of this paper is organised as follows: section two explores the background and justification for this paper and the research questions generated; section three describes the data and methodology; section four reports the results; conclusions are reported in the final section.

\section{Background and questions research}

Financial statements - draw up in compliance with IFRS - report two main measures of overall performance: net income and comprehensive income. IAS 1 identifies different components of "the dirty surplus" that are not recognised in profit or loss (changes in revaluation surplus (IAS 16 and IAS 38), actuarial gains and losses on defined benefit plans recognised in accordance with paragraph 93.a of IAS 19, gains and losses arising from translating the financial statements of a foreign operation (IAS 21), gains and losses on re-measuring available-for-sales financial assets (IAS 39), the effective portion of gains and losses on hedging instruments in a cash flow hedge (IAS 39)). 


\section{Mll Macrothink}

International Journal of Accounting and Financial Reporting

ISSN 2162-3082

2012, Vol. 2, No. 2

Many studies have been carried out on the value relevance of comprehensive income both under IFRSs and under different Accounting Principle, even if the debate is controversial. For instance, Devalle et al. (2010), suggest that "the main aim of IFRS, to improve cross-border comparability of financial statements by means of harmonization of accounting standards, may not have been achieved. Significant differences between European accounting standards still remain and the impact of the introduction of IFRS has been varied". The sample was made up of European listed companies for the six years-period 2002-2007, using both IFRS and non - IFRS data. Devalle at al. (2012) "do not provide evidence that the use of the comprehensive income as the overall economic performance measure results in an unquestionable increase of the value relevance of accounting data" in Europe". The sample was made up of European listed companies for the three years-period 2005-2007. Clarkson et al. (2011), investigated "the impact of IFRS adoption in Europe and Australia on the relevance of book value and earnings for equity valuation". The results showed that IFRS enhanced comparability. Agostino M. et al. (2011) showed that IFRS introduction enhanced the information content of both earnings and book value in bank sector. Ernstberger (2008) compares the value relevance of comprehensive income and net income within German companies which have voluntarily adopted IFRS or US GAAP. Many studies have been made on the value relevance under non IFRS adopter, Kanagaretnam et al. (2009), Dastgir and Velashani (2008), Chambers et al. (2007), Cauwengberde et De Bleede (2007), Wang et al. (2006), Pinto (2005), Maines and McDaniel (2000), Cahan et al. (2000), O' Hanlon and Pope (1999), Dhaliwal et al. (1999), ,Cheng et al. (1993) . Finally, some studies have also been conducted on value relevance and financial crisis. Graham et al. (2000) analysed the effect of the 1997 financial turmoil surrounding the devaluation of the bath affected the value relevance of Thai accounting information. The results showed that value relevance of accounting data were lower after the devaluation of the bath. Also Davis-Friday et al. (2006), examined the effect of financial crisis on the accounting data and corporate governance. They showed that the accounting system affect the extent of changes in the value relevance of book value resulting from the crisis. The results of Ho et al. (2001), indicate that the value relevance of accounting earnings for Korean firms significantly declines from the pre-crisis (1995-1996) to the in crisis (1997-1998) period.

The aim of this paper is to contribute to the literature in two ways. First, the paper provides results by using a wide sample for the four years-period 2006-2009. The high number of observations under IFRS permits to contribute to the value relevance literature. Second, the paper contributes to understand the impact of financial crisis on the association between accounting data and market values.

To reach the objectives described above the question researches are:

1. (Q1) to analyse the value relevance of comprehensive income and net income for a four years period 2006-2009;

2. (Q2) to verify the impact of financial crisis on value relevance of net income and comprehensive income. 


\section{Data and methodology}

\subsection{Data and sample}

The analysis in this paper is based on accounting data hand collected from the annual consolidated financial statements reported by European listed companies. Table 3 reports the number of financial statements included in the final balanced sample.

Table 3. Number of financial statements included in the final balanced sample

\begin{tabular}{|c|c|c|c|c|c|c|c|c|c|c|}
\hline \multirow[b]{3}{*}{ Stock Indexes } & \multirow[b]{3}{*}{$\begin{array}{c}\mathbf{N}^{\circ} \text { OF FIRMS IN } \\
\text { THE INDEX }\end{array}$} & \multicolumn{8}{|c|}{ YEAR } & \multirow[t]{3}{*}{$\begin{array}{r}\text { TOTAL } \\
\text { SAMPLE }\end{array}$} \\
\hline & & \multicolumn{2}{|c|}{2006} & \multicolumn{2}{|c|}{2007} & \multicolumn{2}{|c|}{2008} & \multicolumn{2}{|c|}{2009} & \\
\hline & & Freq. & $\%$ & Freq. & $\%$ & Freq. & $\%$ & Freq. & $\%$ & \\
\hline CAC40 & 40 & 36 & 90 & 36 & 90 & 36 & 90 & 36 & 90 & 144 \\
\hline DAX30 & 30 & 23 & 77 & 23 & 77 & 23 & 77 & 23 & 77 & 92 \\
\hline IBEX 35 & 35 & 32 & 91 & 32 & 91 & 32 & 91 & 32 & 91 & 128 \\
\hline FTSEMIB40 & 40 & 37 & 93 & 37 & 93 & 37 & 93 & 37 & 93 & 148 \\
\hline Total & 145 & 128 & 88 & 128 & 88 & 128 & 88 & 128 & 88 & 512 \\
\hline
\end{tabular}

The net income and the equity were taken from the Consolidated Balance Sheet and Consolidated Income Statement and the gains and losses recognised directly in equity were collected from the consolidated statement of changes in equity or from the consolidated statement of recognised income and expenses. Market data have been collected from the Stock Exchange. The total amount of financial statements analysed was 580, but a number of firms have been excluded because of the missing values. The market value has been collected with respect to the 3rd month after fiscal year end (as Cormier et al., 2009; Kanagaretnam et al., 2009; Oswald, 2008; Van der Meulen et al., 2007; Hellström, 2006; King and Langli, 1998).

\subsection{Methodology}

In order to assess whether comprehensive income is more meaningful for investors than net income, a value relevance approach has been used in this study in compliance with Devalle et al (2012). Commonly, value relevance studies on comprehensive income use various versions of the Price Regression Model (Kanagaretnam et al., 2009; Barth et al., 2008; Dastgir and Velashani, 2008; Pinto, 2005; Cahan et al., 2000). The price regression model (PRM), as explained by Ota (2003), derives from Ohlson's (1995) Linear Information Model (LIM), which considers abnormal earnings as a first-order auto-regressive (AR(1)) process. The PRM is found in the value relevance literature with the following simplified specification:

$$
P_{i t}=\alpha_{0}+\beta_{1} B_{i t}+\beta_{2} E_{i t}+\varepsilon_{i t}
$$


where $P_{i t}$ is the market value of equity, $B_{i t}$ the book value of equity and $E_{i t}$ the earnings relating to firm $i$ and period $t$.

The price regression model is likely to be affected by scale effects (Wu and $\mathrm{Xu}, 2008$; Easton and Sommers, 2003), which can be mitigated by deflating all variables by the market value of the previous period (Barth et al, 2008; Lang et al., 2006; Aboody et al., 2002; Cahan, 2000; Brown et al., 1999; Easton, 1998). Moreover, according to Ali et Hwang (2000), the deflation of both dependent and independent variables is expected to control for heteroscedasticity. Thus, in this study, the Price Regression Model is specified as follows (M1):

$$
\frac{M V_{i t}}{M V_{i(t-1)}}=\alpha_{0} \frac{1}{M V_{i(t-1)}}+\beta_{1} \frac{B V_{i t}}{M V_{i(t-1)}}+\beta_{2} \frac{N I_{i t}}{M V_{i(t-1)}}+\varepsilon_{i t}
$$

where $M V_{i t}$ is the market value of the equity collected at the $4^{\text {th }}$ month after closing year date, $B V_{i t}$ the book value of the equity and $N I_{i t}$ the net income of the firm $i$ at the period $t$. The total comprehensive income, as specified by IFRSs, is the sum of the net income and the other comprehensive income. Letting $\mathrm{TCI}_{i t}$ equal to the total comprehensive income, then:

$T C I_{i t}=N I_{i t}+O C I_{i t}$

where $\mathrm{OCI}_{i t}$ is the sum of the other comprehensive income components. Thus, (M1) is extended to include also the Other Comprehensive Income components (Cahan et al, 2000) and it is specified as follows:

$$
\frac{M V_{i t}}{M V_{i(t-1)}}=\alpha_{0} \frac{1}{M V_{i(t-1)}}+\beta_{1} \frac{B V_{i t}}{M V_{i(t-1)}}+\beta_{2} \frac{N I_{i t}}{M V_{i(t-1)}}+\beta_{3} \frac{O C I_{i t}}{M V_{i(t-1)}}+\varepsilon_{i t}
$$

where $M V_{i t}$ is the market value of the equity collected at the $4^{\text {th }}$ month after closing year date, $B V_{i t}$ the book value of the equity, $N I_{i t}$ the net income and $O C I_{i t}$ the sum of the other comprehensive income relating to firm $i$ and period $t$.

One of the aim of this research is to verify whether the comprehensive income is more value relevant than net income. To reach this purpose it is necessary to assess whether the explained variance $\left(\mathrm{R}^{2}\right)$ increases when the other comprehensive income $\left(O C I_{i t}\right)$ are added to the net income in order to obtain the comprehensive income ${ }^{1}$. The question can be solved by testing the hypothesis that the OCI coefficient is not null.

$\mathrm{H}_{0}: \beta_{\mathrm{OCI}}=0$

An incremental F-test is used to test "null" hypothesis is that $\mathrm{H}_{0}: \beta_{\mathrm{OCI}}=0$, i.e. the "nested" model is superior, in term of explained variance, to the "full" model ${ }^{2}$. The F- test is specified

\footnotetext{
${ }^{1}$ A methodology based on nested regression models and F-tests been already used by Cheng et al. (1993) to evaluate the relative information content of the comprehensive income, by Barth et al. (1996) to evaluate the value-relevance of banks' fair value disclosures reported under US GAAP, by Cahan et al. (2000) to assess the incremental value relevance of the FASB comprehensive income components, by Gjerde et al. (2008) to assess the marginal or incremental value-relevance of IFRS earnings and by Hollister et al. (2008) to evaluate the incremental information content of accounting accruals in predicting future cash flows.

${ }^{2}$ In our paper the "nested" model is that including $B V_{i t}$ and $N I_{i t}$ only, while the "full" model is the one including also OCI ${ }_{i t .}$
} 
as follows ${ }^{3}$ :

$F=\frac{\left(R S S_{1}-R S S_{2}\right) /\left(k_{2}-k_{1}\right)}{R S S_{2} /\left(n-k_{2}-1\right)}$

Where:

$\mathrm{RSS}_{1}=$ residual sum of squares of the nested model;

$\mathrm{RSS}_{2}=$ residual sum of squares of the full model;

$\mathrm{k}_{1}=$ number of estimated coefficients (including constant) for the restricted model;

$\mathrm{k}_{2}$ = number of estimated coefficients (including constant) for the unrestricted model;

$\mathrm{n}=$ total number of observations.

\section{Results}

\subsection{Preliminary analysis}

Table 4 reports descriptive statistics for the variables included in the regression models.

Table 4. Descriptive statistics (by index)

\begin{tabular}{llccccccc}
\hline Variables & Index & N & Mean & Std. Dev. & 95\% confidence interval & Median & Variance \\
& & & & & & & & \\
\hline MV / MV t-1 & CAC 40 & 144 & 1,07733 &, 134704 & 1,05514 & 1,09952 & 1,04646 &, 018 \\
& DAX 30 & 92 & 1,06307 &, 100421 & 1,04227 & 1,08387 & 1,03956 &, 010 \\
& IBEX 35 & 128 & 1,04854 &, 135113 & 1,02491 & 1,07217 & 1,01202 &, 018 \\
& FTSE MIB & 148 & 1,08630 &, 166847 & 1,05920 & 1,11341 & 1,04155 &, 028 \\
\hline BV/ MV t-1 & CAC 40 & 144 & 0,81093 & 0,753045 & 0,68685 & 0,93500 & 0,61790 &, 753 \\
& DAX 30 & 92 & 0,80652 & 0,730898 & 0,65516 & 0,95789 & 0,62084 &, 731 \\
& IBEX 35 & 128 & 0,61720 & 0,396599 & 0,54783 & 0,68656 & 0,54948 &, 396 \\
& FTSE MIB & 148 & 1,20908 & 1,609707 & 0,94759 & 1,47057 & 0,70964 &, 610 \\
\hline NI / MV t-1 & CAC 40 & 144 &, 05969 &, 169575 &, 03176 &, 08762 &, 06272 &, 029 \\
& DAX 30 & 92 &, 06875 &, 101198 &, 04779 &, 08970 &, 06512 &, 010 \\
& IBEX 35 & 128 &, 08800 &, 069539 &, 07583 &, 10016 &, 07818 &, 005 \\
& FTSE MIB & 148 &, 06759 &, 127416 &, 04689 &, 08829 &, 06998 &, 016 \\
\hline OCI / MV t-1 & CAC 40 & 144 &,- 05286 &, 195013 &,- 08498 &,- 02074 &,- 00602 &, 038 \\
& DAX 30 & 92 &,- 02351 &, 090516 &,- 04226 &,- 00476 &,- 00565 &, 008 \\
& IBEX 35 & 128 &,- 02455 &, 150968 &,- 05096 &, 00185 &,- 00167 &, 023 \\
& FTSE MIB & 148 &,- 01842 &, 141229 &,- 04136 &, 00453 &,- 00316 &, 020 \\
\hline
\end{tabular}

\footnotetext{
${ }^{3}$ Stock J., Watson M. (2007), Introduction to Econometrics, Pearson Education.
} 
A two-group means comparison test ( $t$ test) has been run to assess whether the differences among country means are significant. With reference to the variables used in the price regression model (M1 and M2), there are few cases where the country mean significantly differs from the mean of the other countries. According to Table 4, in fact, we can observe that the mean values of the variables used in the regression models don't differ significantly between the different countries analysed. Only the mean values that refer to the ratio BV/MVt-1 - observed for the Italian companies belonging to FTSE MIB - are higher in comparison with the same ratio of the other countries.

The variables reported in Table 4 can also be analysed splitting the data by financial crisis occurrence (Table 4.1).

Table 4.1. Descriptive statistics (by financial crisis occurrence)

\begin{tabular}{|c|c|c|c|c|c|c|c|c|}
\hline Variables & $\begin{array}{l}\text { Financial } \\
\text { Crisis } \\
\text { Occurrence }\end{array}$ & $\mathrm{N}$ & Mean & Std. Dev. & $\begin{array}{l}95 \% \\
\text { interval }\end{array}$ & confidence & Median & Variance \\
\hline \multirow{2}{*}{$\begin{array}{l}\mathrm{MV} / \mathrm{MV} \\
\mathrm{t}-1\end{array}$} & Pre-crisis & 256 & 1,04641 & ,099305 & 1,03419 & 1,05864 & 1,03778 &, 010 \\
\hline & Post-crisis & 256 & 1,09391 &, 168383 & 1,07319 & 1,11464 & 1,03167 &, 028 \\
\hline \multirow{2}{*}{$\begin{array}{l}\mathrm{BV} / \\
\mathrm{MVt}-1\end{array}$} & Pre-crisis & 256 & ,58334 & ,473688 &, 52504 & 64164 & ,46730 & ,473 \\
\hline & Post-crisis & 256 & 1,17026 & 1,336314 & 1,00578 & ,13347 & ,86817 & 1,336 \\
\hline \multirow{2}{*}{$\begin{array}{l}\text { NI/ } \\
\text { MVt-1 }\end{array}$} & Pre-crisis & 256 & ,06562 &, 064058 & ,05774 & ,07351 & ,06095 & ,004 \\
\hline & Post-crisis & 256 & ,07573 & ,166188 & ,05528 & ,09619 & ,08022 & ,028 \\
\hline \multirow{2}{*}{$\begin{array}{l}\text { OCI/ } \\
\text { MVt-1 }\end{array}$} & Pre-crisis & 256 &,- 02573 &, 148268 &,- 04398 &,- 00748 &,- 00294 &, 022 \\
\hline & Post-crisis & 256 &,- 03538 & ,159599 &,- 05502 &,- 01573 &,- 00550 &, 025 \\
\hline
\end{tabular}

All the variables used in the regression models have higher average values for the financial data collected with reference to the years after the crisis. The higher value presented in post financial crisis period are probably due to the downfall of the different European Stock Exchange which meant that the deflators (market values) decreased. In particular, the largest deviations could be noticed in the BM/MVt-1 variable in which there is an higher deviation not only in mean values, but also in standard deviation, in median values and in the confidence interval.

As each comprehensive income component is not always reported by companies, Table 5 reports the number of valid observations collected by country and by year for each 
component.

Table 5. Number of valid observations of comprehensive income components.

\begin{tabular}{|c|c|c|c|c|c|c|c|c|c|c|c|c|c|c|c|c|}
\hline \multirow{2}{*}{$\begin{array}{l}\text { Comprehensive } \\
\text { income } \\
\text { components }\end{array}$} & \multicolumn{4}{|c|}{ CAC 40} & \multicolumn{4}{|c|}{ DAX 30} & \multicolumn{4}{|c|}{ IBEX 35} & \multicolumn{4}{|c|}{ FTSE MIB } \\
\hline & 2006 & 2007 & 2008 & 2009 & 2006 & 2007 & 2008 & 2009 & 2006 & 2007 & 2008 & 2009 & 2006 & 2007 & 2008 & 2009 \\
\hline Cash Flow Hedge & 31 & 23 & 29 & 31 & 20 & 18 & 21 & 22 & 23 & 23 & 24 & 26 & 27 & 28 & 22 & 33 \\
\hline Available for Sale & 23 & 16 & 26 & 30 & 17 & 15 & 17 & 15 & 17 & 19 & 23 & 24 & 21 & 22 & 25 & 24 \\
\hline Revaluation & 2 & 12 & 1 & 1 & 2 & 2 & 2 & 2 & 3 & 3 & 1 & 1 & 2 & 2 & 2 & 1 \\
\hline $\begin{array}{l}\text { Translation } \\
\text { Adjustment }\end{array}$ & 33 & 29 & 31 & 31 & 22 & 22 & 22 & 22 & 29 & 28 & 26 & 27 & 23 & 22 & 25 & 25 \\
\hline $\begin{array}{l}\text { Actuarial Gains } \\
\text { and Losses }\end{array}$ & 9 & 24 & 20 & 20 & 13 & 14 & 15 & 15 & 6 & 8 & 9 & 9 & 6 & 6 & 10 & 10 \\
\hline $\begin{array}{l}N^{\circ} \text { of available } \\
\text { observations }\end{array}$ & 36 & 36 & 36 & 36 & 23 & 23 & 23 & 23 & 32 & 32 & 32 & 32 & 37 & 37 & 37 & 37 \\
\hline
\end{tabular}

Revaluation component, is rarely reported to be different from zero and it shows that fair value is rarely adopted when not mandatory. In order to get significant and robust results, descriptive statistics are reported with reference to the whole sample and some country regression estimations are skipped when the number of observations is not significant. Table 6 summarises the descriptive statistics for the variables referring to each comprehensive income component (M5, M6, M7, M8, M9).

Table 6. Descriptive statistics.

\begin{tabular}{|c|c|c|c|c|c|c|c|}
\hline Variables & $\mathbf{N}$ & Mean & Std. Dev. & $\begin{array}{l}95 \% \\
\text { interval }\end{array}$ & confidence & Median & Variance \\
\hline TA / MV t-1 & 417 &,- 0250132 & ,1272777 &,- 037265 & ,0127615 & ,0043779 & ,016 \\
\hline CFH/MVt-1 & 411 &,- 002247 & ,0593145 &,- 007998 & ,0035039 & ,0003769 & ,004 \\
\hline AFS/MV t-1 & 334 &,- 0086520 & ,0983353 &,- 019236 & ,0019324 &,- 000076 & ,010 \\
\hline REV / MV t-1 & 39 &,- 0140455 & ,0567106 &,- 032428 & ,0043379 & ,00043954 &, 003 \\
\hline AGL / MV t-1 & 184 &,- 0097242 & 0520157 &,- 0172901 &,- 0021584 & ,00061396 & ,003 \\
\hline
\end{tabular}


The mean values of the different components ratio show us negative value, even if the impact of each component on the market value is not always the same (this could be also be confirmed by the median values and by the variance that is, for example, higher in TA/MVt-1 variable).

Table 6.1. Descriptive statistics.

\begin{tabular}{lllllllll}
\hline \multirow{2}{*}{ Variables } & $\begin{array}{l}\text { Financial Crisis } \\
\text { Occurence }\end{array}$ & $\mathbf{N}$ & Mean & Std. Dev. & 95\% confidence interval & Median & Variance \\
& Pre-crisis & 208 & $-0,03497$ & 0,159276 & $-0,567383$ & $-0,013193$ & $-0,00753$ & 0,025 \\
\multirow{2}{*}{ TA/MVt-1 } & Post-crisis & 209 & $-0,01511$ & 0,083394 & $-0,026481$ & $-0,003736$ & $-0,00063$ & 0,007 \\
\hline \multirow{2}{*}{ CFH/MVt-1 } & Pre-crisis & 193 & 0,002121 & 0,017123 & $-0,00031$ & 0,004552 & 0,000956 & 0,001 \\
& Post-crisis & 218 & 0,006146 & 0,079724 & $-0,016757$ & 0,004528 & $-0,001114$ & 0,006 \\
\hline \multirow{2}{*}{ AFS/MVt-1 } & Pre-crisis & 150 & $-0,00065$ & 0,040457 & $-0,007176$ & 0,005879 & $-0,000009$ & 0,002 \\
& Post-crisis & 184 & $-0,01518$ & 0,127153 & $-0,033672$ & 0,003318 & $-0,00051$ & 0,016 \\
\hline \multirow{2}{*}{ REV/MVt-1 } & Pre-crisis & 28 & $-0,00318$ & 0,01927 & $-0,010647$ & 0,004297 & 0,000454 & 0,001 \\
& Post-crisis & 11 & $-0,04172$ & 0,100227 & $-0,109049$ & 0,025618 & $-0,000481$ & 0,01 \\
\hline \multirow{2}{*}{ AGL/MVt-1 } & Pre-crisis & 76 & 0,008287 & 0,019968 & 0,003725 & 0,01285 & 0,001778 & 0,001 \\
& Post-crisis & 108 & $-0,0224$ & 0,062891 & $-0,034395$ & $-0,010302$ & $-0,00427$ & 0,004 \\
\hline
\end{tabular}

The same component variables can be analysed grouping the data by financial crisis occurrence as was done previously for the other variables. In this way we can notice that mean and meadian values are lower for data referring post-crisis situation than for data related to the years before the crisis (this is observable in all the variables a part from Translation Adjustment).

\subsection{Regression results}

Regression models have been estimated to assess whether the comprehensive income is more value relevant than the net income $(\mathrm{Q} 1)$ and to verify value relevance before and after financial crisis (Q2). The PRM (price regression model) have been used to answer the question researches.

Table 7, Table 8 and Table 9 report the results of the within-group estimation 4 of the price regression model as specified in the regression model M1. Financial data collected, that refer to the period before financial crisis are the only for which the hypothesis test of null coefficients $\left(\mathrm{H}_{0}: \beta_{1}=\beta_{2}=0\right)$ is not significantly rejected.

\footnotetext{
${ }^{4}$ The choice between a fixed-effect or random-effect estimation has been driven by the Hausman test.
} 
Table 7. M1 estimation results (by index)

\begin{tabular}{lllll}
\hline Variables & CAC40 & DAX30 & FTSE MIB & IBEX35 \\
\hline$\beta_{1}$ & $0.09129 * * *$ & $0.03973 * *$ & $0.022321 * * *$ & $0.091083^{* * * *}$ \\
$\beta_{2}$ & -0.03146 & $0.3224 * * *$ & 0.1029 & $0.3528 *$ \\
$\mathrm{~N}$ & 144 & 92 & 128 & 148 \\
$\mathrm{R}^{2}$ & 0.2378 & 0.1104 & 0.0460 & 0.1243 \\
$\mathrm{~F}\left(\mathrm{H}_{0}: \beta_{\mathrm{i}}=0\right)$ & $23.3 * * *$ & $6.647 * * *$ & $4.547 * *$ & $10.02 * * *$ \\
\hline
\end{tabular}

$M 1: \frac{M V_{i t}}{M V_{i(t-1)}}=\alpha_{0}+\beta_{1} \frac{B V_{i t}}{M V_{i(t-1)}}+\beta_{2} \frac{N I_{i t}}{M V_{i(t-1)}}+\varepsilon_{i t}$

Notes: $* * *$ Denotes p-value $<0.01 . \quad * *$ Denotes p-value $<0.05 *$ Denotes p-value $<0.1$.

Table 8. M1 estimation results (by year)

\begin{tabular}{lllll}
\hline Variables & $\mathbf{2 0 0 6}$ & $\mathbf{2 0 0 7}$ & $\mathbf{2 0 0 8}$ & $\mathbf{2 0 0 9}$ \\
\hline$\beta_{1}$ & 0.03119 & 0.02922 & $0.02113 * * *$ & 0.01929 \\
$\beta_{2}$ & 0.00330 & -0.1247 & 0.00839 & -0.1128 \\
$\mathrm{~N}$ & 128 & 128 & 128 & 128 \\
$\mathrm{R}^{2}$ & 0.0147 & 0.0164 & 0.0810 & 0.0638 \\
$\mathrm{~F}\left(\mathrm{H}_{0}: \beta_{\mathrm{i}}=0\right)$ & 0.9345 & 1.047 & $5.509 * * *$ & $4.261 * *$ \\
\hline
\end{tabular}

$M 1: \frac{M V_{i t}}{M V_{i(t-1)}}=\alpha_{0}+\beta_{1} \frac{B V_{i t}}{M V_{i(t-1)}}+\beta_{2} \frac{N I_{i t}}{M V_{i(t-1)}}+\varepsilon_{i t}$

Notes: *** Denotes p-value $<0.01 . \quad * *$ Denotes $\mathrm{p}$-value $<0.05 *$ Denotes $\mathrm{p}$-value $<0.1$. 
Table 9. M1 estimation results (by financial crisis occurrence)

\begin{tabular}{lll}
\hline Variables & Pre-crisis & Post-crisis \\
\hline$\beta_{1}$ & $0.02112^{*}$ & $0.03245^{* * *}$ \\
$\beta_{2}$ & -0.02919 & $0.1284^{* *}$ \\
$\mathrm{~N}$ & 256 & 256 \\
$\mathrm{R}^{2}$ & 0.01373 & 0.0978 \\
$\mathrm{~F}\left(\mathrm{H}_{0}: \beta_{\mathrm{i}}=0\right)$ & 1.76 & $13.71 * * *$ \\
\hline
\end{tabular}

$M 1: \frac{M V_{i t}}{M V_{i(t-1)}}=\alpha_{0}+\beta_{1} \frac{B V_{i t}}{M V_{i(t-1)}}+\beta_{2} \frac{N I_{i t}}{M V_{i(t-1)}}+\varepsilon_{i t}$

Notes: *** Denotes p-value $<0.01 . \quad * *$ Denotes p-value $<0.05 *$ Denotes p-value $<0.1$.

As we can see from Table 7 and Table 8 the R2 value (using M1 regression model) is higher in CAC 40 listed companies than in the other stock indexes considered in the sample. If we are going to analyse the same variable $\left(\mathrm{R}^{2}\right)$ observing the $\mathrm{M} 1$ estimation results by year, we notice that from 2006 to 2008 the values of the variable considered have increased. On the other hand, in the following years the $\mathrm{R}^{2}$ values had decreased.

Table 10, Table 11 and Table 12 list the results of the within-group estimation of M2. $\beta 3$ is the coefficient of the independent variable referring to the sum of the other comprehensive components.

Table 10. M2 estimation results (by index)

\begin{tabular}{lllll}
\hline Variables & CAC40 & DAX30 & FTSE MIB & IBEX35 \\
\hline$\beta_{1}$ & $0.08113^{* * *}$ & 0.01319 & $0.02221^{* * * *}$ & $0.09114^{* * *}$ \\
$\beta_{2}$ & -0.01605 & $0.2978^{* * * *}$ & -0.07806 & $0.2936^{*}$ \\
$\beta_{3}$ & $-0.01308^{*}$ & $-0.2901^{* *}$ & $-0.3439 * * *$ & $-0.2143 * * *$ \\
$\mathrm{~N}$ & 144 & 92 & 128 & 148 \\
$\mathrm{R}^{2}$ & 0.2833 & 0.1776 & 0.1243 & 0.1947 \\
$\mathrm{~F}\left(\mathrm{H}_{0}: \beta_{\mathrm{i}}=0\right)$ & $18.45^{* * *}$ & $6.335^{* * *}$ & $6.815^{* * *}$ & $9.995 * * *$ \\
\hline
\end{tabular}

$M 2: \frac{M V_{i t}}{M V_{i(t-1)}}=\alpha_{0}+\beta_{1} \frac{B V_{i t}}{M V_{i(t-1)}}+\beta_{2} \frac{N I_{i t}}{M V_{i(t-1)}}+\beta_{3} \frac{O C I_{i t}}{M V_{i(t-1)}}+\varepsilon_{i t}$

Notes: $* * *$ Denotes p-value $<0.01 * *$ Denotes p-value $<0.05 *$ Denotes p-value $<0.1$. 
Table 11. M2 estimation results (by year)

\begin{tabular}{lllll}
\hline Variables & $\mathbf{2 0 0 6}$ & $\mathbf{2 0 0 7}$ & $\mathbf{2 0 0 8}$ & $\mathbf{2 0 0 9}$ \\
\hline$\beta_{1}$ & 0.00312 & 0.02992 & $0.02113^{* *}$ & $0.02345^{* *}$ \\
$\beta_{2}$ & 0.00350 & -0.1246 & 0.00458 & $-0.2387^{* * *}$ \\
$\beta_{3}$ & -0.01315 & -0.01781 & $-0.1783^{* *}$ & $-0.3685^{* * *}$ \\
$\mathrm{~N}$ & 128 & 128 & 128 & 128 \\
$\mathrm{R}{ }^{2}$ & 0.01486 & 0.01756 & 0.1241 & 0.1588 \\
$\mathrm{~F}\left(\mathrm{H}_{0}: \beta_{\mathrm{i}}=0\right)$ & 0.6234 & 0.7387 & $5.856 * * *$ & $7.801 * * *$ \\
\hline
\end{tabular}

$M 2: \frac{M V_{i t}}{M V_{i(t-1)}}=\alpha_{0}+\beta_{1} \frac{B V_{i t}}{M V_{i(t-1)}}+\beta_{2} \frac{N I_{i t}}{M V_{i(t-1)}}+\beta_{3} \frac{O C I_{i t}}{M V_{i(t-1)}}+\varepsilon_{i t}$

Notes: $* * *$ Denotes p-value $<0.01 * *$ Denotes p-value $<0.05 *$ Denotes p-value $<0.1$.

Table 12. M2 estimation results (by financial crisis occurrence)

\begin{tabular}{lll}
\hline Variables & Pre-crisis & Post-crisis \\
\hline$\beta_{1}$ & $0.03145^{*}$ & $0.03411^{* * *}$ \\
$\beta_{2}$ & -0.00908 & 0.08210 \\
$\beta_{3}$ & -0.00149 & $-0.3727^{* * *}$ \\
$\mathrm{~N}$ & 256 & 256 \\
$\mathrm{R}^{2}$ & 0.0142 & 0.2176 \\
$\mathrm{~F}\left(\mathrm{H}_{0}: \beta_{\mathrm{i}}=0\right)$ & 1.212 & $23.36 * * *$ \\
\hline
\end{tabular}

$M 2: \frac{M V_{i t}}{M V_{i(t-1)}}=\alpha_{0}+\beta_{1} \frac{B V_{i t}}{M V_{i(t-1)}}+\beta_{2} \frac{N I_{i t}}{M V_{i(t-1)}}+\beta_{3} \frac{O C I_{i t}}{M V_{i(t-1)}}+\varepsilon_{i t}$

Notes: *** Denotes p-value $<0.01 * *$ Denotes p-value $<0.05 *$ Denotes p-value $<0.1$.

According to Table 10 and Table 11, we can notice higher $\mathrm{R}^{2}$ values (compared with the previous model) regarding CAC 40, DAX 30 and FTSE MIB. Analysing M2 Model, and splitting the results by year, we can confirm the R2 trend reported above (a part from 2007 observations). Tables 13,14, 15 reports incremental f-test of nested analysis. 
Table 13. Incremental F-test of M1 nested in M2

\begin{tabular}{lllll}
\hline & F & Pr>F & Change in $\mathbf{R}^{\mathbf{2}}$ & $\mathbf{H}_{\mathbf{0}}: \boldsymbol{\beta}_{\mathbf{3}}=\mathbf{0}$ \\
\hline CAC40 & 6.8164 & 0.0101 & 0.0455 & Rejected at 0.05 level \\
DAX30 & 5.1000 & 0.0264 & 0.0672 & Rejected at 0.05 level \\
FTSE MIB & 10.739 & 0.0013 & 0.0783 & Rejected at 0.05 level \\
IBEX35 & 8.7173 & 0.0037 & 0.0704 & Rejected at 0.01 level \\
\hline
\end{tabular}

Table 14. Incremental F-test of M1 nested in M2

\begin{tabular}{lllll}
\hline & $\mathrm{F}$ & $\mathrm{Pr}>\mathrm{F}$ & Change in $\mathrm{R}^{2}$ & $\mathrm{H}_{0}: \beta_{3}=0$ \\
\hline 2006 & 0.0159 & 0.8998 & 0.0002 & Not Rejected \\
2007 & 0.1370 & 0.7120 & 0.0012 & Not Rejected \\
2008 & 6.0998 & 0.0149 & 0.0431 & Rejected at 0.05 level \\
2009 & 13.994 & 0.0002 & 0.0950 & Rejected at 0.01 level \\
\hline
\end{tabular}

Table 15. Incremental F-test of M1 nested in M2

\begin{tabular}{lllll}
\hline & $\mathrm{F}$ & $\mathrm{Pr}>\mathrm{F}$ & Change in $\mathrm{R}^{2}$ & $\mathrm{H}_{0}: \beta_{3}=0$ \\
\hline Pre-crisis & 0.1263 & 0.7226 & 0.0005 & Not Rejected \\
Post-crisis & 38.577 & 0.0001 & 0.1198 & Rejected at 0.01 level \\
\hline
\end{tabular}

Findings show that the $\beta 3$ is statistically significant only in IBEX 35 listed companies (p-value < 0.01) and in FTSE MIB listed companies ( $p$-value < 0.01). Moreover, the results of the incremental F-test leads to the rejection of the null hypothesis $\mathrm{H}_{0}: \beta_{3}=0$ for all the European stock indexes considered in the sample (as reported in Table 13).

We can also analyse the value relevance of total comprehensive income splitting the data by financial crisis scenario. According to Table 9, Table 12 and Table 15, we can see that other comprehensive income increase the value relevance of accounting data only for the data collected in reference to the years after the financial crisis. In addition it is observable that the increase in $\mathrm{R}^{2}$ values is higher for data referring to post-crisis situation, for which F-test is more statistically significant compared to the pre-crisis results ( $\mathrm{p}$-value $<0.01$ ). To summarise, 
the findings of the price regression model within-group estimation do not provide a clear evidence of an increase of the value relevance when the comprehensive income is used instead of net income, but rather suggest that the sum of the other comprehensive income components are rarely statistically significant. We can also notice that Total Comprehensive income is more value relevant than net income in the years after financial crisis.

\section{Conclusion}

In this article, I analyze the value relevance of accounting data, and the consequences of financial crisis on value relevance of the net income and comprehensive income. To this end, we estimate price regression model using a sample of listed companies belonging to the main European stock indexes (CAC40, DAX30, IBEX35, FTSE MIB) for the period 2006-2009. We also employ an incremental F-test to verify whether the use of the comprehensive income instead of the net income significantly increases the explanatory power of the value relevance models. With reference to the first question research the findings do not provide evidence that the use of the comprehensive income as the overall economic performance measure results in an unquestionable increase of the value relevance of accounting data. These results are consistent with previous literature (e.g. Devalle et al. (2010, 2012). For the 2006-2009 period France, Spain, Germany and Italy report that comprehensive income is more value relevant than the net income, but opposite findings arise from the model estimation that consider only data collected before the financial crisis: the data collected referring to the financial statements of the years before financial crisis show that comprehensive income is not so value relevant as in the post-crisis scenario.

\section{References}

Aboody D., Hughes J., Liu J., 2002. Measuring value relevance in a (possibly) inefficient market. Journal of Accounting Research 40 (4), 965-986

Agostino, M., Drago, D., and Silipo, D., 2010. The value relevance of IFRS in the European banking industry. Review of quantitative finance and accounting, 20 (June), $1-21$

Ali A., Hwang L. S., 2000. Country-Specific factors related to financial reporting and the value relevance of accounting data. Journal of Accounting Research 38 (1), 1-21

Barth M., Beaver W., Landsman W., 1996. Value-relevance of banks' fair value disclosures under SFAS No. 107. The Accounting Review 71 (4), 513-537

Barth M., Landsman W., Lang M., 2008. International Accounting Standards and Accounting Quality. Journal of Accounting Research 43 (3), 467-498

Brown S., Lo K., Lys T, 1999. Use of R2 in accounting research: measuring changes in value relevance over the last four decades. Journal of Accounting and Economics 28, 83-115

Cahan S.F., Courtenay S.M., Gronewoller P.L., Upton D.R. 2000. Value relevance of mandated comprehensive income disclosures. Journal of Business, Finance and Accounting 27 (9), 1273-1301

Cauwenberge P.W., De Bleede I., 2007. On the IASB comprehensive income project: an 
analysis of the case for dual income display. Abacus 43 (1), 1-26

Chambers D., Linsmeier T.J., Shakespeare C., Sougiannis T., 2007. An evaluation of SFAS No. 130 comprehensive income disclosure. Review of Accounting Studies, 12, 557-593

Cheng A.C.S., Chueng J.K., Gopalakrishnan V. 1993. On the usefulness of operating income, net income and comprehensive income in explaining security returns. Accounting and Business Research, 23 (91), 195-203

Clarkson P., Douglas H., Richardson G. D., Thompson R.c (2011). The impact of IFRS adoption on the value relevance of book value and earnings, Journal of Contemporary Accounting \& Economics, Volume 7, Issue 1, June 2011, Pages 1 - 17

Cormier D., Demaria S., Lapointe-Antunes P., Teller R., 2009. First-time adoption of IFRS, managerial incentives, and value-relevance: some French evidence. Journal of International Accounting Research 8 (2), 1-22

Dastgir M., Velashani A.S. 2008. Comprehensive income and net income as measures of performance: some evidence for scale effect, European Journal of Economics. Finance and Administrative Sciences, 12, 123-133

Davis-Friday P, Eng L, Liu C.., 2006. The effects of the Asian crisis, corporate governance and accounting system on the valuation of book value and earnings, The International Journal of Accounting, 41, 22-40.

Devalle A., Magarini R., 2012 Assessing the value relevance of total comprehensive income under IFRS: an empirical evidence from European Stock Exchanges, International Journal of Accounting, Auditing and Performance Evaluation

Devalle A., Magarini R. (University of Turin), Onali E. (University of Bangor) 2010, Assessing the value relevance of accounting data after IFRS introduction in Europe, Journal of Financial Management \& Accounting, Volume 21, Number 2

Dhaliwal D., Subramanyam K.R., Trezevant R. 1999. Is comprehensive income superior to net income as a measure of firm performance?. Journal of Accounting and Economics, 26, 43-67

Easton P. Sommers G. 2003. Scale and scale effects in market-based accounting research. Journal of Business Finance and Accounting 30 (1), 25-55

Ernstberger J., 2008. The value relevance of comprehensive income under IFRS and US GAAP: empirical evidence from Germany. Journal in Accounting, Auditing and Performance Evaluation 5, 1-29

Grahan R., King R., Bailes J., 2000. The Value Relevance of Accounting information during a Financial Crisis: Thailand and the 1997 Decline in the Value of the Bath. Journal of International Financial Management and Accounting, 11:2

Gjerde Ø., Knivsfla K., Sættem F., 2008. The value-relevance of adopting IFRS: Evidence from 145 NGAAP restatements. Journal of International Accounting, Auditing and Taxation 17, 92-112 


\section{I Macrothink}

International Journal of Accounting and Financial Reporting

ISSN 2162-3082

2012, Vol. 2, No. 2

Hellström K., 2006. The value relevance of financial accounting information in a transition economy: the case of Czech Republic, European Accounting Review, 15 (3), 325-349

Ho L., Liu C., Sik Sohn P., 2001. The value relevance of accounting information around the 1997 Asian financial crisis - the case of South Korea, Asia-Pacific Journal of Accounting \& Economics, 8:2, 83-107

Hollister J., Shoaf V., Tully G., 2008. The effect of accounting regime characteristics on the prediction of future cash flows: an international comparison. International Business \& Economics Research Journal, 7, 15-30

Kanagaretnam K., Mathieu R., Shehata M., 2009. Usefulness of comprehensive income reporting in Canada. Journal of Accounting and Public Policy 28, 349-365

King R., Langli J. 1998. Accounting Diversity and Firm Valuation, The Journal of International Accounting, 33 (5), 529-567

Lang M., Raedy J.S., Wilson W., 2006. Earnings management and cross listing: are reconciled earnings comparable to US earnings?. Journal of Accounting and Economics 42, $255-283$

Maines L.A., McDaniel L.S., 2000. Effects of comprehensive income characteristics on nonprofessional investors' judgements: the role of financial statement presentation format. The Accounting Review 75, 179-207

O'Hanlon J., Pope P.F., 1999. The value relevance of UK dirty surplus accounting flows. British Accounting Review, 31, 459-482

Ohlson J., 1995. Earnings, book values and dividends in equity valuation, Contemporary Accounting Research, 11, 661-687

Oswald D., 2008. The determinants and value relevance of the choice of accounting for research and development expenditures in the United Kingdom. Journal of Business Finance \& Accounting 35(1) \& (2), 1-24

Ota K., 2003. The impact of price and returns models on value-relevance studies: a review of theory and evidence, Accounting Research Journal 16, 6-20

Pinto J. A. 2005. How comprehensive is comprehensive income? The value relevance of foreign currency translation adjustments. Journal of International Financial Management and Accounting, 16, 97-122

Stock J., Watson M., 2007. Introduction to Econometrics, Addison-Wesley / Prentice Hall

Van der Meulen S., A. Gaeremynck, M. Willekens, 2007. Attribute differences between U.S. GAAP and IFRS earnings: an explanatory study, The International Journal of Accounting, 42, $123-142$

Wang Y., Buijink W., Eken R., 2006. The value relevance of dirty surplus accounting flows in The Netherlands. The International Journal of Accounting 41, 387-405

Wu C., Xu B., 2008. Deflator selection and generalized linear modelling in market-based regression analyses, Applied Financial Economics, 18, 1739-1753 


\section{Macrothink \\ International Journal of Accounting and Financial Reporting \\ ISSN 2162-3082 \\ 2012, Vol. 2, No. 2}

\section{Copyright Disclaimer}

Copyright reserved by the author(s).

This article is an open-access article distributed under the terms and conditions of the Creative Commons Attribution license (http://creativecommons.org/licenses/by/3.0/). 